\title{
WALT WHITMAN IN TRIMMING SQUARE
}

Walt Whitman's familiar and helpful notebook entry about the succession of residences that he and his family occupied on Long Island contains a teasing entry near its end:

In Jamaica first time in the latter part of the summer of 1839. In the winter succeeding, I taught school between Jamaica and Flushing-also in February and spring of ' 40 at Triming Square-In summer of 40 I taught at Woodbury. ${ }^{1}$

Where is Trim[m]ing Square? Local historians on Long Island, who are assiduous about such things in the grand tradition of local historians, had not kept records with the name. And Whitman scholarship was largely in the dark about it. Gay Wilson Allen wrote in The Solitary Singer, "From Little Bay Side [the school Whitman described as being between Jamaica and Flushing] Whitman returned to the West Hills region, where he taught during the spring of 1840 at Triming Square (no longer found on Long Island maps) and the following summer at Woodbury, three or four miles from West Hills."2

Indeed it is no longer found on Long Island maps, but it is real and it is not near West Hills. The best lead to the location of the town is in Walt Whitman on Long Island by Bertha H. Funnell, who almost pinpointed its location; she seems to place it a bit northeast of its actual center but is apparently the only Whitman scholar to come even close to the real location. ${ }^{3}$ Her source was an entertaining and fact-crammed old history of Long Island, Daniel Tredwell's Personal Reminiscences of Men and Things on Long Island, a book that is apparently alone among the histories, gazettes, maps, and official records in preserving the name of Trimming Square (two m's). ${ }^{4}$

Trimming Square was a notable community by contemporary standards; it lay about two miles west of Hempstead, covered at least fifteen square miles, and centered on the intersection of Jamaica Road (today Hempstead Turnpike) and John Street (today Nassau Boulevard), which means that it was a sizable part of present day West Hempstead and the southern part of Garden City up as far as present-day Adelphi University and the site of the former St. Paul's School. At an unrecorded time the name of Trimming Square was changed to Washington Square; later the community became Munson and still later an anonymous neighborhood of West Hempstead.

Whitman's school served what was then and is still District 17 and stood on John Street in the acute angle formed by the intersection of Dogwood Avenue. A photograph found by Paul Van Wie and reproduced here shows the school early in the twentieth century shortly before it was torn down; a large wing (on the right in the picture) had been added by that time. (The school's modern successor, about two hundred yards to the north of the old school's site, is still named the John Street School, to the mystification, no doubt, of many residents who know nothing of the street's old name.)

As of April 1840, according to the Hempstead Town Records, school had been kept in the district for five months and twenty-one days, of which four months and twenty days were by an "approved teacher"-presumably Whitman, for the four-and-one-half-month period would fit neatly between the dates 
of the preceding and following teaching jobs that Whitman lists in his notebook. ${ }^{5}$ For teachers' salaries the district received $\$ 56.10$ in public money and $\$ 55.81$ from other sources; it is impossible to tell from the records how much of this amount went to Whitman and how much to any teacher who may have preceded him. The number of children in the district older than five and younger than sixteen - the school ages - was ninety-five, and the number actually taught in the school was sixty-three. The school was inspected once in the course of the school year and had thirty-three volumes in its library. Families living in the district, whose children would have attended the school, had such old Long Island names as Eldert, Hewlett, Nostrand, Carman, Mott, and Duryea; Whitman would have "boarded around" with the families of his students. ${ }^{6}$

From the fact that we have no record of Whitman's impressions of Trimming Square we may be able to conclude that they were not bad, for it was his very next job in Woodbury that occasioned Whitman's terribly funny letters about the "gump-heads" he was forced to live among. One of the redeeming things about Trimming Square in Whitman's eyes may have been the varied population attracted by the town's best known institution, the Washington Race Course, which since the seventeenth century had been one of America's best known racetracks; the track was also the site of the annual "Huckleberry Frolic," renowned for its ribaldry, dissipation, and knavery. ${ }^{7}$

The Trimming Square months were productive ones for Whitman as a writer. "The Sun-Down Papers. -From the Desk of a Schoolmaster" began to appear in the nearby Hempstead Inquirer during that time, and there are

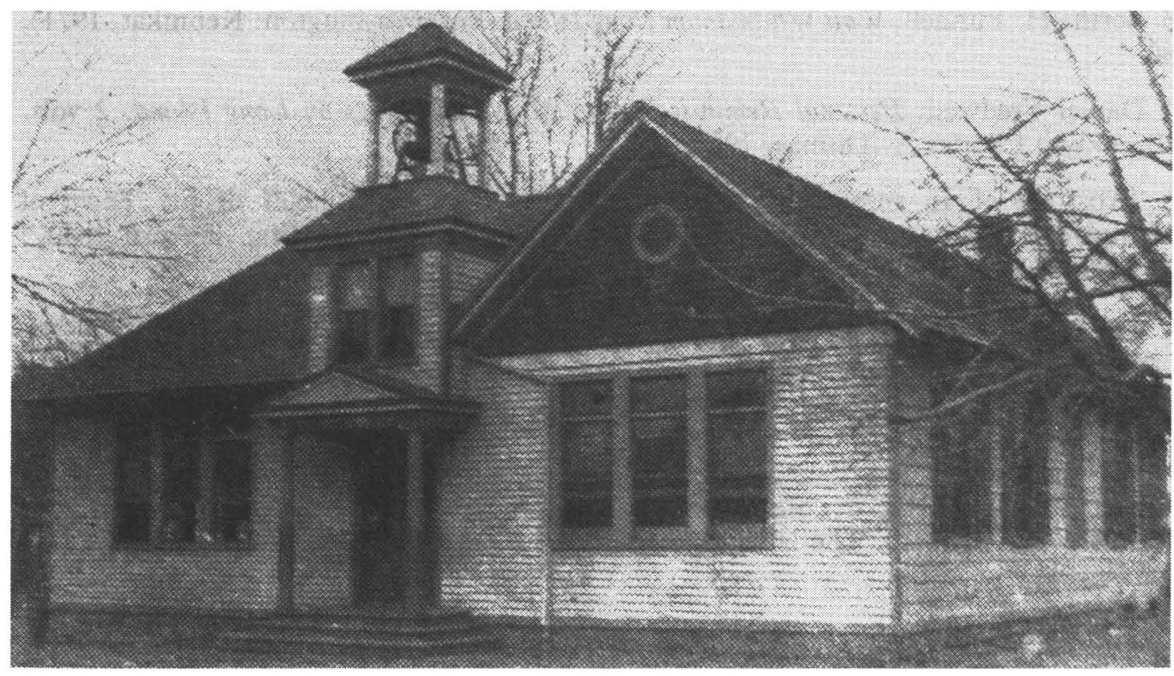

The only known photograph of Whitman's old Trimming Square school. This early twentieth-century picture shows the school shortly before its demolition; the wing on the right had been added since Whitman's time. Courtesy of Paul Van Wie and the Franklin Square Historical Society. Reproduced from the Franklin Square Bulletin (March 13, 1941). 
suggestions from internal evidence that other contributions to the Inquirer were from Whitman's pen. ${ }^{8}$ (The Inquirer, incidentally, provides a good picture of the cultural events available in the town, an easy walk from Trimming Square.) Whatever poetry Whitman wrote in Trimming Square was juvenilia and possibly included such pieces as "Young Graves" and "The Inca's Daughter."

The research that unearthed Trimming Square led to a symposium, "Walt Whitman Here in Trimming Square," October 30, 1992, at Adelphi University, the grounds of which lay in the old Whitman school district. It came to mind at the time that Emory Holloway, who did so much of his Whitman work while teaching at Adelphi (and at least one of whose former students was at the symposium), would have enjoyed knowing that he was working on ground where Whitman may have "boarded around."

Adelphi University

Thomas Farel HefFernan

\section{NOTES}

1 From Walt Whitman, The Uncollected Poetry and Prose of Walt Whitman, Much of Which Has Been But Recently Discovered, With Various Early Manuscripts, ed. Emory Holloway (Garden City: Doubleday, Page \& Co., 1921. 2 vols.; repr. Gloucester: Peter Smith, 1972), 2:86-87. Other version with editorial explanation in Walt Whitman, Notebooks and Unpublished Prose Manuscripts, ed. Edward F. Grier (New York: New York University Press, 1984), 1:209.

2 Gay Wilson Allen, The Solitary Singer: A Critical Biography of Walt Whitman (New York: Macmillan, 1955), 37.

3 Bertha H. Funnell, Walt Whitman on Long Island (Port Washington: Kennikat, 1971), 60 .

4 Daniel Tredwell, Personal Reminiscences of Men and Things on Long Island. 2 vols. (Brooklyn: Charles A. Ditmas, 1912).

5 "Abstract of an annual report of trustees of Common Schools of the Town of Hempstead. Made to the Commissioner of Schools of Said the first of April 1840," Hempstead Town Records, vol. 6 (1784-1862).

6 The names of residents come from, among other sources, the Walling Map of Queens County (1859).

7 Tredwell, 209-211.

8 For the "Sun-Down Papers" see UPP, 1:32-51, and H. Bergmann and William White, "Whitman's Lost 'Sun-down Papers', Nos. 1-3," American Book Collector 20 (January 1970), 17-20. The latter article explains confusion over the numbering of the Papers. 